\title{
The Concentrations of Calcium Buffering Proteins in Mammalian Cochlear Hair Cells
}

\author{
Carole M. Hackney, ${ }^{1,2}$ Shanthini Mahendrasingam, ${ }^{1}$ Andrew Penn, ${ }^{1}$ and Robert Fettiplace ${ }^{3}$ \\ ${ }^{1}$ MacKay Institute of Communication and Neuroscience, School of Life Sciences, Keele University, Keele, Staffordshire ST5 5BG, United Kingdom, and \\ Departments of ${ }^{2}$ Anatomy and ${ }^{3}$ Physiology, University of Wisconsin Medical School, Madison, Wisconsin 53706
}

Calcium buffers are important for shaping and localizing cytoplasmic $\mathrm{Ca}^{2+}$ transients in neurons. We measured the concentrations of the four main calcium-buffering proteins (calbindin-D28k, calretinin, parvalbumin- $\alpha$, and parvalbumin- $\beta$ ) in rat cochlear hair cells in which $\mathrm{Ca}^{2+}$ signaling is a central element of fast transduction and synaptic transmission. The proteins were quantified by calibrating immunogold tissue counts against gels containing known amounts of each protein, and the method was verified by application to Purkinje cells in which independent estimates exist for some of the protein concentrations. The results showed that, in animals with fully developed hearing, inner hair cells had $1 / 10$ of the proteinaceous calcium buffer of outer hair cells in which the cell body contained parvalbumin- $\beta$ (oncomodulin) and calbindin-D28k at levels equivalent to $5 \mathrm{~mm}$ calcium-binding sites. Both proteins were partially excluded from the hair bundles, which may permit fast unbuffered $\mathrm{Ca}^{2+}$ regulation of the mechanotransducer channels. The sum of the calcium buffer concentrations decreased in inner hair cells and increased in outer hair cells as the cells developed their adult properties during cochlear maturation. The results suggest that $\mathrm{Ca}^{2+}$ has distinct roles in the two types of hair cell, reflecting their different functions in auditory transduction. $\mathrm{Ca}^{2+}$ is used in inner hair cells primarily for fast phase-locked synaptic transmission, whereas $\mathrm{Ca}^{2+}$ may be involved in regulating the motor capability underlying cochlear amplification of the outer hair cell. The high concentration of calcium buffer in outer hair cells, similar only to skeletal muscle, may protect against deleterious consequences of $\mathrm{Ca}^{2+}$ loading after acoustic overstimulation.

Key words: cochlea; calcium; calbindin-D28k; calretinin; hair cells; immunocytochemistry; oncomodulin; parvalbumin- $\alpha$; postembedding labeling

\section{Introduction}

Detection, amplification, and relay of acoustic information in the mammalian cochlea are accomplished by two classes of sensory receptor, the inner and outer hair cells. Primary information is conducted via the inner hair cells and their synapses onto the auditory nerve afferents, whereas outer hair cells act in parallel to boost the stimulus by electromechanical amplification (Dallos, 1992). Several facets of transduction involve intracellular calcium, including adaptation of mechanotransducer channels (Fettiplace and Ricci, 2003), afferent synaptic transmission (Brandt et al., 2003; Fuchs et al., 2003), and outer hair cell contractility (Dulon et al., 1990; Dallos et al., 1997; Frolenkov et al., 2000). The central role of calcium is underscored by the hearing loss resulting from mutations in the plasma membrane CaATPase (Kozel et al., 1998; Street et al., 1998), the extrusion path that maintains the ion at a low cytoplasmic concentration (Tucker and Fettiplace, 1995; Yamoah et al., 1998). Because the two hair cell types have distinct roles and calcium-driven mechanisms, it might be ex-

Received March 28, 2005; revised July 18, 2005; accepted July 19, 2005.

This work was supported by grants from the Graduate School, University of Wisconsin (C.M.H., R.F.) and National Institute on Deafness and Other Communication Disorders Grant R01 DC 01362 (R.F.). We are grateful to Michael Henzl for the gifts of oncomodulin and its antibody.

Correspondence should be addressed to Robert Fettiplace, University of Wisconsin Medical School, 185 Medical Sciences Building, 1300 University Avenue, Madison, WI 53706. E-mail: fettiplace@physiology.wisc.edu. DOI:10.1523/JNEUROSCI.1196-05.2005

Copyright $\odot 2005$ Society for Neuroscience $\quad$ 0270-6474/05/257867-09\$15.00/0 pected that they differ in their calcium-handling proteins. For example, the CaATPase isoform PMCA1 [plasma membrane $\mathrm{Ca}^{2+}$-ATPase] is essentially confined to inner hair cells, whereas PMCA2a is most concentrated in outer hair cell stereociliary bundles (Dumont et al., 2001). There is also dichotomy with respect to calcium-binding proteins thought to play a role in buffering cytoplasmic calcium transients. Immunolabeling of adult cochleas has suggested that calretinin and the $\alpha$ isoform of parvalbumin occur only in inner hair cells (Dechesne et al., 1991, 1994; Pack and Slepecky, 1995; Soto-Prior et al., 1995; Yang et al., 2004 ), but the $\beta$-isoform of parvalbumin, also known as oncomodulin (Pauls et al., 1996), is concentrated in outer hair cells (Sakaguchi et al., 1998; Hackney et al., 2003). The fourth major calcium-buffering protein, calbindin-D28k, is found in both hair cell types (Pack and Slepecky, 1995; Imamura and Adams, 1996).

All four calcium-binding proteins are diffusible and may therefore be important in limiting the spread of calcium to prevent interaction between calcium-signaling pathways in different parts of the cell (Roberts, 1994). To relate the qualitative distributions of the calcium-binding proteins to cell function, it is necessary to know their respective cytoplasmic concentrations. Here we present data quantifying the four proteins in both inner and outer hair cells, and we track the changes in their concentrations over the period when the hair cells develop their distinct adult properties. This quantification was achieved in ultrathin sections of the organ of Corti using a method that calibrates 
immunogold tissue counts against gels containing known amounts of recombinant protein (Kosaka et al., 1993; Hackney et al., 2003). Our results indicate that, in animals with fully developed hearing, inner hair cells showed much smaller amounts of calcium buffer than outer hair cells, which contained parvalbumin- $\beta$ and calbindin-D28k at levels equivalent to $5 \mathrm{~mm}$ calcium-binding sites. The high concentration of calcium buffer in outer hair cells implies that calcium plays an important role in cell function, but neither its source nor target is fully understood.

\section{Materials and Methods}

Antibodies and purified proteins. Commercially available polyclonal antibodies to rat parvalbumin- $\alpha$ (PV28) and parvalbumin- $\beta$ (OM3) were supplied by Swant (Bellinzona, Switzerland) and to recombinant rat calbindin-D28k and calretinin by Chemicon (Temecula, CA). A mouse monoclonal antibody to frog muscle parvalbumin- $\alpha$ (clone PARV-19) was obtained from Sigma (St. Louis, MO). In addition, Dr. Michael Henzl of the University of Missouri (Columbia, MO) kindly provided a mouse monoclonal antibody against parvalbumin- $\beta$ (OMM). The secondary antibodies for postembedding immunolabeling were $15 \mathrm{~nm}$ colloidal gold-conjugated anti-rabbit and anti-mouse IgGs (British Biocell, Cardiff, UK). The purified proteins used for preadsorption controls and for calibration gels (see below) were recombinant rat calbindin-D28k, human calretinin (6-His-CR), rat parvalbumin- $\alpha$, and parvalbumin- $\beta$ (all from Swant). Dr. Henzl also provided us with pure rat parvalbumin- $\beta$ protein.

Animals. Cochlear segments were isolated from Sprague Dawley rats using procedures approved by the Animal Care Committee at the University of Wisconsin and in accordance with the UK Animals (Scientific Procedures) Act of 1986. Tissue was obtained from animals of both sexes on postnatal day 7 (P7), P16, and P26. Preyer reflex tests indicated that the P16 and P26 animals had acoustic startle responses but that the P7 animals did not. This accords with previous reports that indicate electrical responses to sound cannot be recorded in rats until the second postnatal week, with the onset of hearing occurring at approximately postnatal day 12 , and auditory sensitivity continues to improve until postnatal day 30 (Crowley and Hepp-Reymond, 1966; Uziel et al., 1981; Blatchley et al., 1987).

For tissue fixation, animals were deeply anesthetized with ketamine $(50-100 \mathrm{mg} / \mathrm{kg})$ and xylazine $(4-8 \mathrm{mg} / \mathrm{kg})$ or with sodium pentobarbitone (Pentoject; $100 \mathrm{mg} / \mathrm{kg}$ ) injected intraperitoneally. After loss of the pedal withdrawal reflex, they were perfused transcardially for $1 \mathrm{~min}$ with a vascular flush of buffered saline containing 5\% dextran or heparin $(7.2$ $\mathrm{U} / \mathrm{ml}$ ) and $0.15 \%$ procaine $\mathrm{HCl}$ and then for 10 min with $4 \%$ paraformaldehyde and $0.1 \%$ glutaraldehyde in $0.1 \mathrm{~m}$ sodium phosphate buffer (PB), pH 7.4. The perfusion commenced within a few seconds of opening the thorax, and tissue was only used from animals whose neck had become stiff within $2 \mathrm{~min}$. At the end of the perfusion, the animals were decapitated, the auditory bullae were opened, and each cochlea was fixed further by perfusion of the same fixative via small holes made in the cochlear base and apex, followed by immersion in the fixative for $2 \mathrm{~h}$ at room temperature.

To obtain cerebellar tissue to use the Purkinje cells as a positive tissue control for the immunoquantitative procedure, two P29 rats were deeply anesthetized with an intraperitoneal injection of sodium pentobarbitone (Pentoject; $100 \mathrm{mg} / \mathrm{kg}$ ). After loss of the pedal withdrawal reflex, they were perfused transcardially with a vascular flush and then with the same fixative as for the cochlear preparations. The animals were decapitated, and the cranium was removed to expose the brain, which was left in the same fixative for $1 \mathrm{~h}$ at room temperature. Frontal 100 - to $400-\mu \mathrm{m}$-thick sections of the cerebellum were cut using a vibratome and processed for electron microscopy in the same way as the cochlear segments.

Electron microscopy and immunogold labeling. Cochlear segments and pieces of cerebellum were dissected out and washed in PB and then dehydrated in a graded series of ethanols. The pieces of tissue were infiltrated with LR-White resin (Agar Scientific, Stansted, UK) for $24 \mathrm{~h}$ and placed in gelatin capsules for polymerization of the resin at $50^{\circ} \mathrm{C}$ for an additional $24 \mathrm{~h}$. Ultrathin $(120 \mathrm{~nm})$ sections were cut on a Leica (Nuss- loch, Germany) Ultracut ultramicrotome and collected on 300-mesh nickel grids. The grids were washed in $0.05 \mathrm{~m}$ Tris-buffered saline (TBS), $\mathrm{pH} 7.4$, and nonspecific protein binding was blocked using $20 \%$ goat serum in TBS for $30 \mathrm{~min}$. They were then incubated overnight at $4^{\circ} \mathrm{C}$ in the appropriate primary antibody diluted in TBS containing $1 \%$ bovine serum albumin (BSA) as follows: polyclonal anti-calbindin-D28k, polyclonal anti-calretinin, and monoclonal anti-parvalbumin- $\beta$ (1:500); monoclonal anti-parvalbumin- $\alpha$ (1:200); polyclonal anti-parvalbumin- $\beta$ and anti-parvalbumin- $\alpha$ (1:5000). This was followed by washing in $1 \%$ BSA-TBS and incubation in an appropriate secondary antibody, either goat anti-rabbit IgG or goat anti-mouse IgG, conjugated to $15 \mathrm{~nm}$ gold diluted 1:20 in 1\% BSA-TBS for $2 \mathrm{~h}$ at room temperature. The grids were washed again in TBS, followed by distilled water. The sections were stained with $2 \%$ aqueous uranyl acetate for $20 \mathrm{~min}$, followed by lead citrate for 1-2 min, and examined using a JEOL-100CX (JEOL, Welwyn Garden City, UK) transmission electron microscope operated at an accelerating voltage of $100 \mathrm{kV}$.

Analysis of immunogold labeling densities. The density of gold labeling was determined in radial sections of the cochleas taken from an apical low-frequency region, $6-8 \mathrm{~mm}$ from the stapes, and from a basal highfrequency region, $1-3 \mathrm{~mm}$ from the stapes. These locations correspond to characteristic frequencies of $\sim 6$ and $\sim 30 \mathrm{kHz}$, respectively (Müller, 1991). A random sampling method was then used to determine the density of gold particles in the hair cells. To count the number of gold particles in the cytoplasm of hair cells, mitochondria-free areas were randomly selected at low magnification $(4800 \times)$ at which the gold particles were not visible. The magnification was then increased $(48,000 \times)$ so that gold particles could be counted within the same field of view on the transmission electron microscope. Multiple fields of view were sampled in each case (see below). A similar method was used to determine the densities of gold particles in the nucleus, but, for stereocilia, transverse sections were used and their total area in the field of view was determined.

Preadsorption controls. For negative controls for the antibodies to calbindin-D28k and calretinin, $1 \mu \mathrm{g}$ of the reconstituted purified protein was added to $100 \mu \mathrm{l}$ of the appropriate antibody solution (diluted 1:500), mixed thoroughly, and incubated for $6 \mathrm{~h}$ at $4^{\circ} \mathrm{C}$ on a rotator. For a negative control of parvalbumin- $\beta, 2.4 \mu \mathrm{g}$ of reconstituted recombinant oncomodulin (lot number 13.4; Swant) was also added to $100 \mu \mathrm{l}$ of the appropriate antibody solution (diluted 1:500). For negative controls for parvalbumin- $\alpha, 1-2 \mu \mathrm{g}$ of recombinant rat muscle parvalbumin- $\alpha$ was added to $1 \mathrm{ml}$ of diluted (1:5000) anti-parvalbumin- $\alpha$ solution. The information of the manufacturers (with the exception of Swant) indicated that the antibody concentration was $1-3 \mathrm{mg} / \mathrm{ml}$, and, when diluted, it had a concentration of $\sim 10 \mathrm{~nm}$. The amounts of purified calciumbinding protein used for antibody preadsorption yielded final protein concentrations of between 0.15 and $2 \mu \mathrm{M}, 10$ - to 100 -fold in excess of the antibody. For the Swant antibodies, the dilutions used were as specified by the protocol of Swant for adsorption in their product descriptions. In each case after mixing the antigen and antibody, the preadsorbed antibody solution was centrifuged for $10 \mathrm{~min}$, and the supernatant was used in parallel with the unadsorbed primary antibody. [The control antibody solution was treated in exactly the same way (including centrifugation) as the preadsorbed antibody solution.] These procedures eliminated the labeling by the antibody in each case.

Determination of hair cell buffer concentrations. To establish the concentration range of calbindin, calretinin, and parvalbumin in mammalian hair cells, a calibration procedure was used similar to that used to determine their levels in turtle hair cells (Hackney et al., 2003). A solution of each protein in 10\% BSA in $4 \%$ paraformaldehyde in PB was made, and the mixture was solidified into a gel by the addition of $0.1 \%$ glutaraldehyde. A 1-2 mm block of each gel was dehydrated and embedded in resin in the same manner as the tissue prepared for transmission electron microscopy to provide a protein standard. Ultrathin sections were then cut onto nickel grids from the standard and immunolabeled with the relevant primary antibody and gold-conjugated secondary antibody under the same conditions and in parallel with the labeling of a cochlear sample. To ensure identical labeling conditions, both the standard and cochlear sections were processed at the same time and in the same fluid drop. Gels were made with the protein concentrations in the range of 


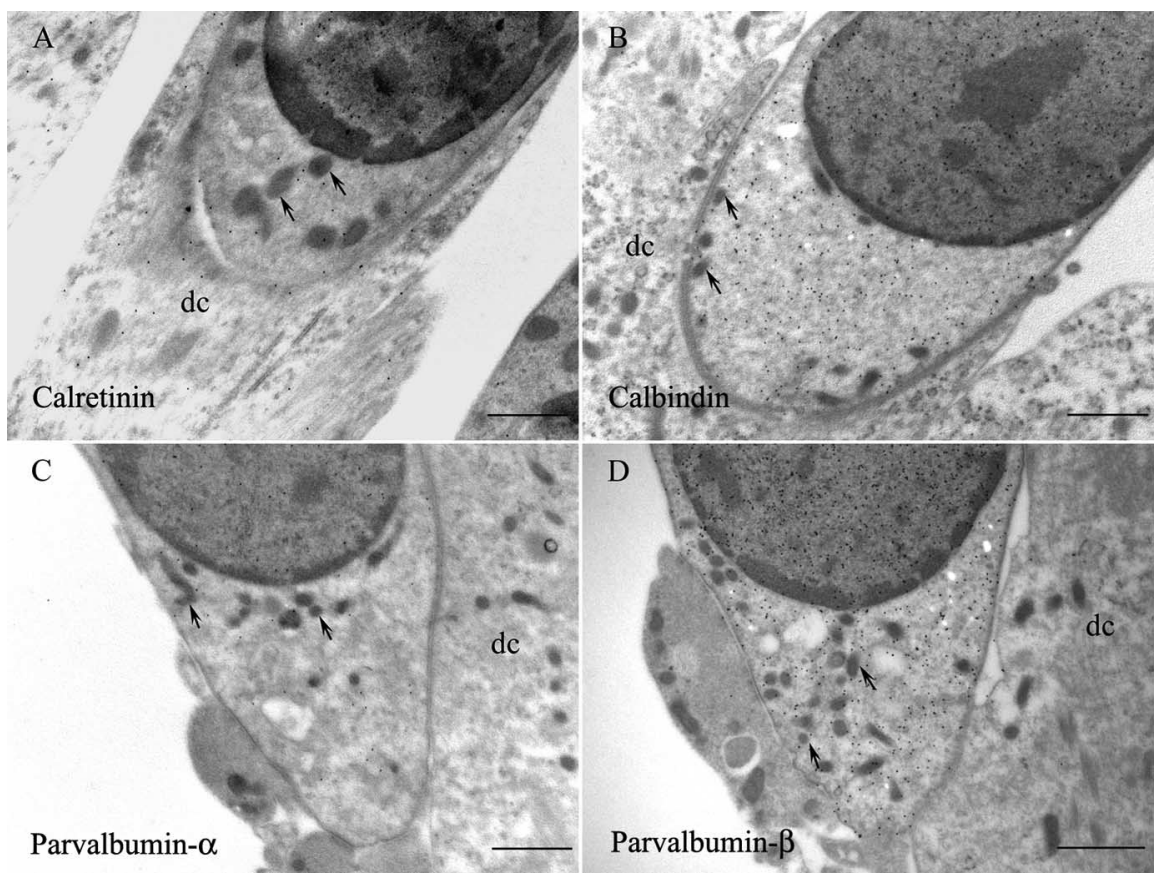

Figure 1. Postembedding immunogold labeling of P16 rat outer hair cells and adjacent supporting cells with antibodies to calcium-binding proteins. $\boldsymbol{A}$, Calretinin; $\boldsymbol{B}$, calbindin-D28k; $\boldsymbol{C}$, parvalbumin- $\alpha ; \boldsymbol{D}$, parvalbumin- $\beta$. Note the labeling of the hair cell cytoplasm and nucleus in each case but not the mitochondria (examples at arrows). Also note the lack of labeling in the adjacent Deiters' cells (dc), except in the case of calretinin in $\boldsymbol{A}$. The labeling for calretinin in particular is also heavier in the nucleus than in the cytoplasm. Scale bars, $1.0 \mu \mathrm{m}$. nuclear region and perilymphatic surface of outer hair cells from P16 rats with fully developed hearing. Examples of labeling in the hair bundle and endolymphatic aspect of both outer and inner hair cells are illustrated in Figures 2 and 3. Labeling was confined to the hair cells for all proteins except calretinin, which was also present in nerve terminals and in the nonsensory Deiters' and pillar cells (Fig. 1A). For each of the proteins, labeling was distributed throughout the cytoplasm, both above and below the nucleus, and was found in the cuticular plate and to a lesser extent in the stereocilia (see below). For all four proteins, label was also found in the nucleus, the relative abundance in different intracellular compartments being, nucleus $\approx$ cuticular plate $\geq$ apical cytoplasm $>$ stereocilia.

A slightly greater labeling of the nucleus than in the neighboring cytoplasm was found for parvalbumin- $\beta$ (Fig. $1 D$ ), but a more pronounced twofold to threefold higher nuclear than cytoplasmic labeling was observed for calretinin (Fig. 1A). The reason for the difference for calretinin is unclear, but it was also seen in turtle auditory hair cells (Hackney et al., 2003).

As will be discussed in the next section 5-225 $\mu \mathrm{M}$ (calretinin, $5 \mu \mathrm{M}$; calbindin-D28k, 5 and $225 \mu \mathrm{M}$; parvalbumin- $\alpha$, 10 and $100 \mu \mathrm{M}$; parvalbumin- $\beta, 40$ and $100 \mu \mathrm{M})$. Because of the limited availability of the protein antigen, the protein concentration in the gel was in some cases (especially with parvalbumin- $\beta$ ) less than predicted for the tissue. This required extrapolation based on the linearity derived from the two gel concentrations. Because the immunogold labeling will eventually saturate with increasing antigen concentration, the extrapolation would, if anything, have led to an underestimate in the tissue concentration of the calcium-binding protein. The density of gold particles over a series of fields of view of sections of the standard gels was then compared with the density of the gold particles in the hair cells and used to estimate the concentrations of each of the proteins in each of the subcellular compartments measured. As an additional check of the specificity of the antibodies to the two forms of parvalbumin, immunogold labeling was performed on sections from a parvalbumin- $\alpha$ gel with the antibody to parvalbumin $-\beta$ and on a parvalbumin- $\beta$ gel with the antibody to parvalbumin- $\alpha$. In each case, the labeling was found to be very sparse and no higher than that of the background level on resin-only areas $\left(<0.1\right.$ particles $\left./ \mu \mathrm{m}^{2}\right)$.

Numbers of experiments. The results are based on two animals at each postnatal age, one animal being used to test and optimize the labeling conditions and the other to take the measurements. For each antibody and cochlear location, multiple fields of view were sampled, and measurements were averaged over the fields of view of both inner and outer hair cells. Between 40 and 268 fields of view were averaged for each experimental condition. There was no substantive evidence for differences between the three rows of outer hair cells, so the results were pooled across the rows. The number of averages $(n)$ was therefore larger for the outer hair cells. Values are quoted as mean \pm 1 SEM.

\section{Results}

Patterns of hair cell labeling for calcium-binding proteins

Robust immunolabeling for calbindin-D28k, calretinin, and both $\alpha$ - and $\beta$-isoforms of parvalbumin was evident in highresolution electron micrographs of the organ of Corti (Figs. 1-3). Figure 1 shows labeling for each of the antibodies around the proteins), labeling for all four proteins changed with postnatal development. Examples of these changes for hair cells in the cochlear apex are illustrated for the two proteins showing the most pronounced developmental variation: parvalbumin- $\beta$ in Figure 2, $A$ and $B$, and calbindin-D28k in Figure 3. Each figure shows a radial section of the apex of a hair cell, including the stereocilia, cuticular plate, and underlying cytoplasm. For parvalbumin- $\beta$, labeling of the cell body was more intense in outer hair cells from P26 post-hearing animals (Fig. $2 \mathrm{~B}$ ) than in either outer hair cells from $\mathrm{P} 7$ pre-hearing animals (Fig. $2 \mathrm{~A}$ ) or in inner hair cells from P26 animals (Fig. 2C). In contrast, the cell bodies of inner hair cells from P7 pre-hearing animals (Fig. $3 A$ ) were more intensely labeled for calbindin-D28k than were $\mathrm{P} 26$ post-hearing animals (Fig. 3B).

\section{Quantification of immunogold labeling of calcium-binding proteins}

The strength of the labeling depends on the efficacy of the antibody as well as on the protein concentration. The density of labeling alone can therefore be a misleading gauge of the abundance of the antigen. To deduce a protein concentration, the density of gold particles was calibrated by comparison with the immunogold labeling of a section of aldehyde-fixed gel containing a known amount of the protein (Hackney et al., 2003). In our previous study of turtle hair cells (Hackney et al., 2003), as a test of this quantification technique, calcium buffer concentrations in hair cells derived using gel standards were compared with estimates obtained from quantitative immunoblots. The two techniques were in remarkably close agreement given that, for estimates derived from quantitative immunoblots, it was necessary to assume a volume fraction of the turtle cochlea occupied by the hair cells compared with other tissue compartments. Here, the
(Quantification of immunogold labeling of calcium-binding 
A

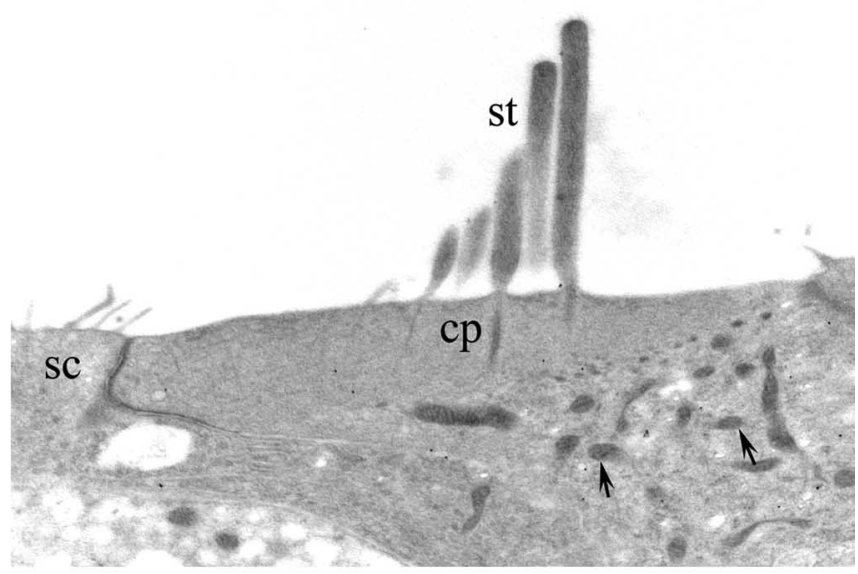

P26 OHC

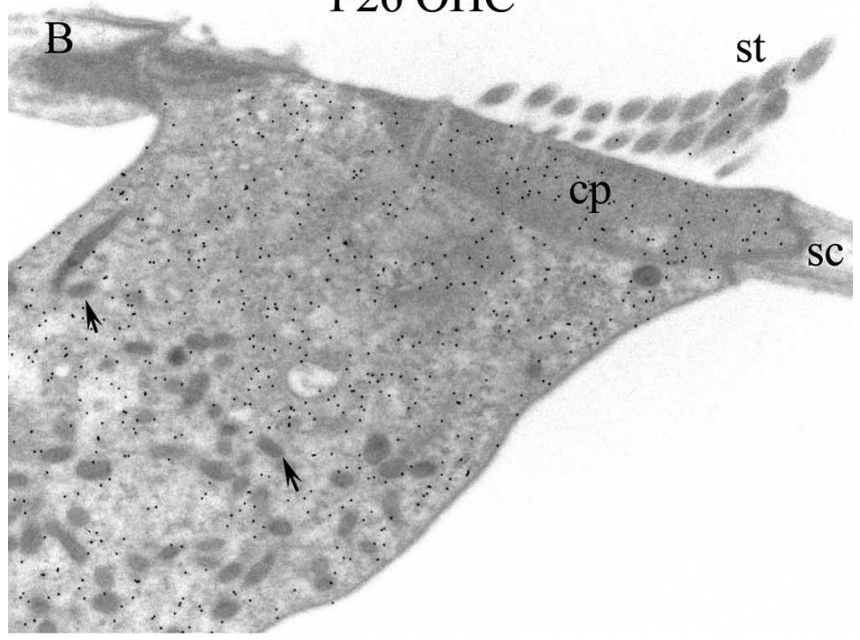

$\mathrm{C}$

P26 IHC

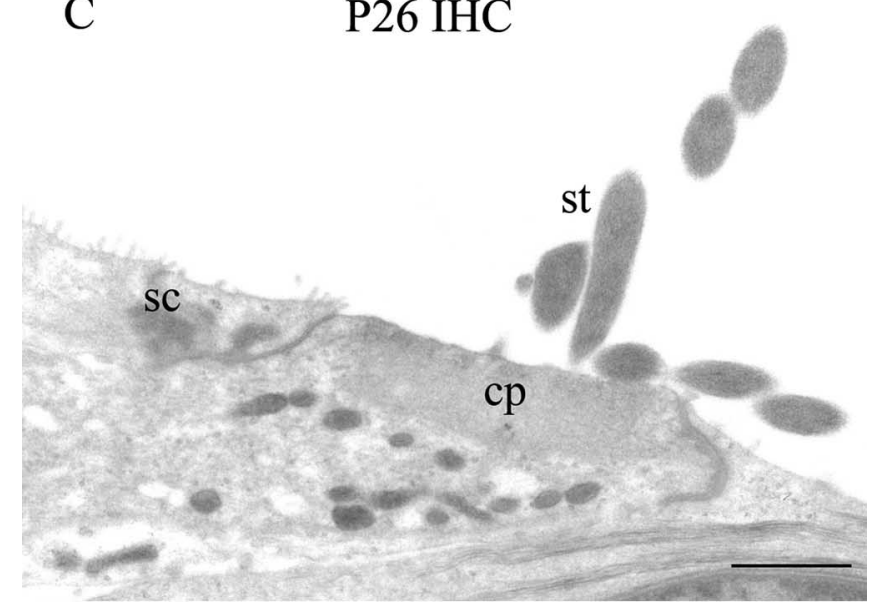

Figure 2. Postembedding immunogold labeling for parvalbumin- $\beta$ in outer and inner hair cells. $A$, Outer hair cell (OHC) from a P7 non-hearing rat. $B$, Outer hair cell from a P26 rat showing increased labeling in an animal with fully developed hearing. $C$, Inner hair cell (IHC) from a P26 rat. All three sections were obtained from the cochlear apex and labeled with a monoclonal anti-parvalbumin- $\beta$ antibody. Note the labeling of cuticular plates (cp) and hair cell cytoplasm but the absence of labeling in the mitochondria (examples at arrows) and adjacent supporting cells (sc). The labeling is higher in the cytoplasm and cuticular plate of the P26 outer hair cell than the P7 outer hair cell, and there is negligible labeling of the P26 inner hair cell. At both ages, the stereocilia (st) are less labeled than the adjacent cuticular plate. Scale bar, $1.0 \mu \mathrm{m}$.

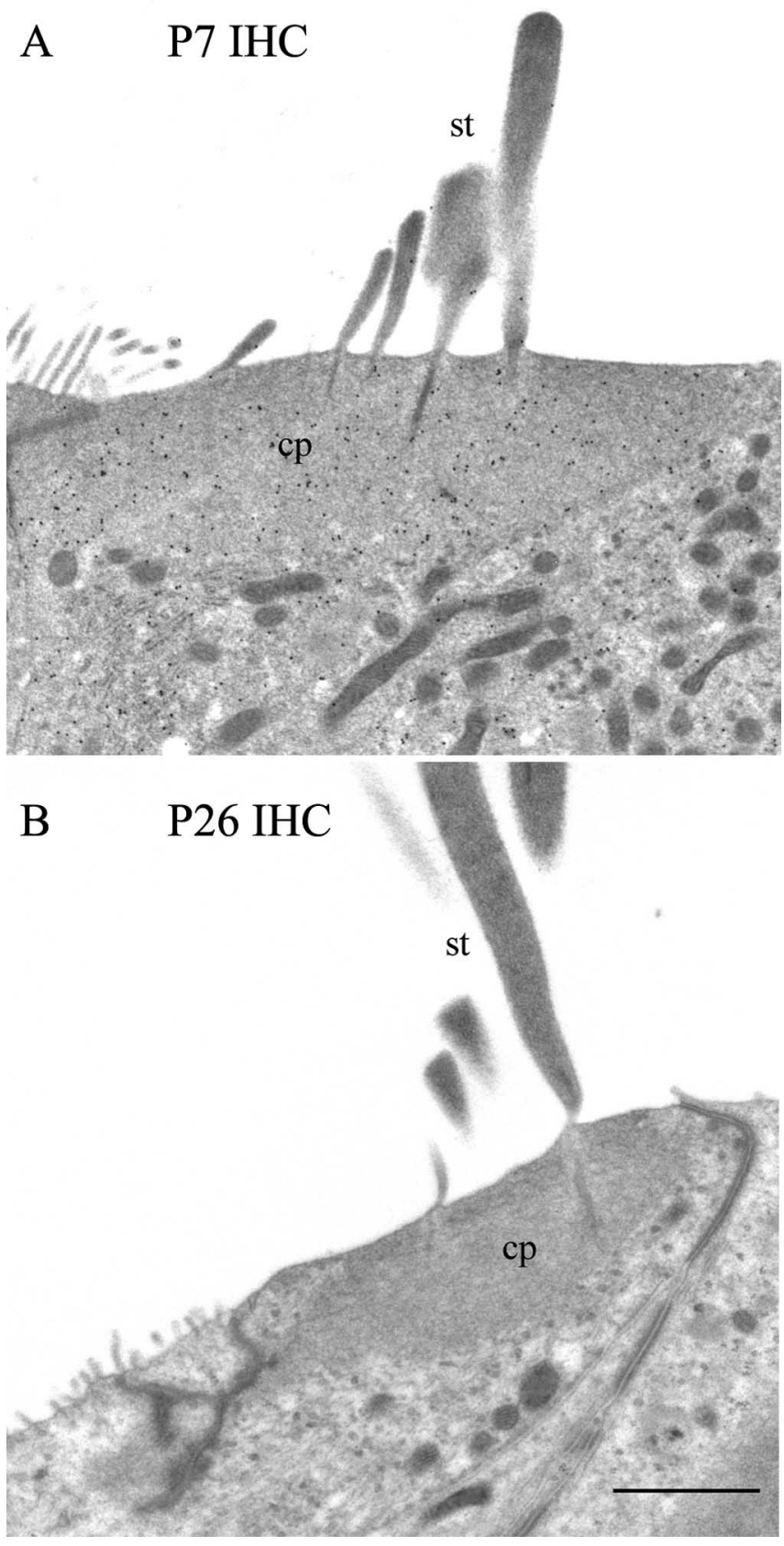

Figure 3. Effect of age on the postembedding immunogold labeling of apical inner hair cells for calbindin-D28k. $A$, Inner hair cell (IHC) apex (endolymphatic aspect) from a P7 non-hearing rat. $\boldsymbol{B}$, Inner hair cell apex from a P26 rat with fully developed hearing. The labeling is much higher in the cytoplasm and cuticular plate (cP) at P7 than at P26. Note also that the stereocilia (st) are less labeled than the cuticular plate at P7. Scale bar, $1.0 \mu \mathrm{m}$.

validity of the technique was further verified for calbindin-D28k and parvalbumin- $\alpha$ by applying it to cerebellum in which other methods have demonstrated the occurrence of both proteins in Purkinje cells. Calibration of gold particle densities in five Purkinje cell somas gave concentrations of $116 \pm 30 \mu \mathrm{M}$ for parvalbumin- $\alpha$ and $208 \pm 42 \mu \mathrm{M}$ for calbindin-D28k. These values agree well with independent estimates (parvalbumin- $\alpha$, 50-100 $\mu \mathrm{M}$; calbindin-D28k, 210-360 $\mu \mathrm{M}$ ) using biochemical, immunocytochemical, or radioimmunoassay methods (Baimbridge et al., 1982; Kosaka et al., 1993; Plogmann and Celio, 1993; Schwaller et al., 2002). 
A

Inner hair cell

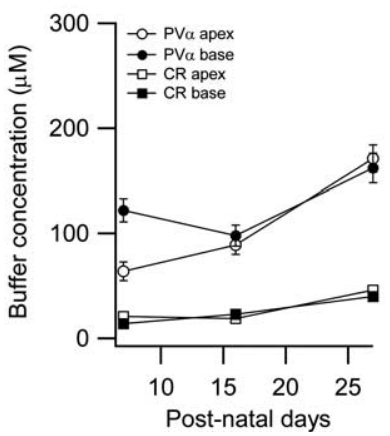

B

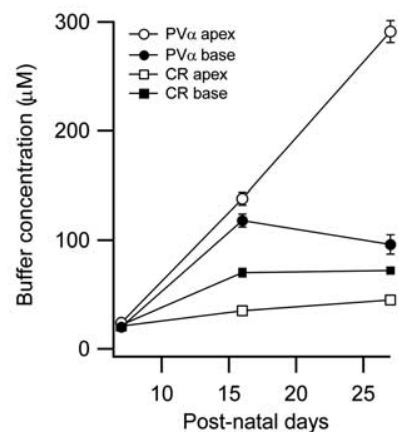

Figure 4. Changes in concentration of calretinin and parvalbumin- $\alpha$ in inner and outer hair cells during cochlear development. Plots showing the average amounts of calretinin (CR) and parvalbumin- $\alpha(\mathrm{PV} \alpha)$ present in inner hair cells $(\boldsymbol{A})$ and outer hair cells $(\boldsymbol{B})$ at P7, P16, and P26. Numbers of field of view averaged for calretinin were 70-121 (inner hair cells) and 182-264 (outer hair cells). Numbers of field of view averaged for parvalbumin- $\alpha$ were 64-102 (inner hair cells) and 75-207 (outer hair cells). Error bars denote 1 SEM.
A

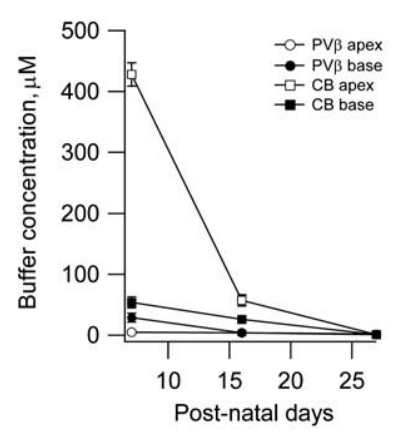

B

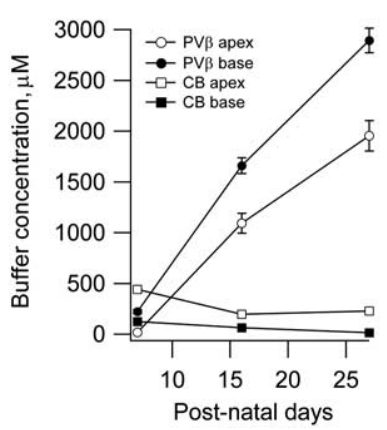

Figure 5. Changes in concentration of calbindin-D28k and parvalbumin- $\beta$ during cochlear development. Plots showing the average amounts of calbindin-D28k (CB) and parvalbumin- $\beta$ $(\mathrm{PV} \beta)$ present in inner hair cells $(\boldsymbol{A})$ and outer hair cells $(\boldsymbol{B})$ at P7, P16, and P26. Note that the amount of calbindin-D28k declines from P7 to P26 particularly in the hair cells at the apex of the cochlea, whereas parvalbumin- $\beta$ disappears from the inner hair cells but increases dramatically in the outer hair cells. Error bars are SEM; when the bars are not visible, they are smaller than the symbols used to denote the point. Numbers of field of view averaged for calbindin-D28k were 40-125 (inner hair cells) and 57-197 (outer hair cells). Numbers of field of view averaged for parvalbumin- $\beta$ were 55-104 (inner hair cells) and 188-268 (outer hair cells). Error bars denote 1 SEM. Note the sixfold difference in the ordinate scale for the inner hair cells compared with outer hair cells.

Applying the calibration procedure to immunogold labeling of hair cells showed that, in rats after the onset of hearing at approximately postnatal day 12 , the calcium-binding proteins were less concentrated in inner hair cells than in outer hair cells, in which the major constituent was parvalbumin- $\beta$ at a concentration of 2-3 mM. No consistent difference in labeling between the three rows of outer hair cells was found, and so the values quoted are averages across the three rows. In contrast to parvalbumin- $\beta$, the three other calcium-binding proteins were present at much lower levels. The collected results for the four calcium-binding proteins are documented in Figures 4 and 5. For example, the concentrations in apical inner and outer hair cells, respectively, of P16 rats were as follows: calbindin-D28k, $57 \pm 9$ $\mu \mathrm{M}(n=45)$ and $196 \pm 16 \mu \mathrm{M}(n=197)$; calretinin, $19 \pm 2 \mu \mathrm{M}$ $(n=90)$ and $35 \pm 3 \mu \mathrm{M}(n=218)$; parvalbumin- $\alpha, 89 \pm 9 \mu \mathrm{M}$ $(n=87)$ and $138 \pm 6 \mu \mathrm{M}(n=266)$, in which $n$ denotes the numbers of fields of view that were averaged. There were small, at most twofold, differences in concentration between apical and basal locations.

Different antibodies to the same protein could give different values for the cellular concentrations. Values within a factor of two were obtained using the monoclonal or polyclonal antibodies to parvalbumin- $\beta$. However, although the two antibodies against parvalbumin- $\alpha$, a monoclonal antibody (PARV-19 made against a frog antigen) and a polyclonal antibody (PV28 made against a rat antigen) showed comparable cellular distributions and age trends, the absolute protein concentrations were more than fivefold larger with the polyclonal antibody. The reason for this difference is unclear, but the higher values of concentration are quoted. Testing of both parvalbumin- $\alpha$ antibodies against gels containing parvalbumin- $\beta$ gave no measurable labeling, indicating that neither antibody showed any cross-reactivity.

\section{Developmental changes in calcium-binding proteins}

Parvalbumin- $\beta$ and calbindin-D28k demonstrated the most striking changes during development. Examples of the changes in labeling are shown for outer hair cells in Figure 2, $A$ and $B$, and for inner hair cells in Figure 3, $A$ and $B$, and the variations in concentration with development are given in Figure 5. In P7 rats, the predominant calcium-buffering protein is calbindin-D28k, which has a similar concentration of $\sim 400 \mu \mathrm{M}$ in apical inner and outer hair cells. However, with cochlear maturation, the calbindin-D28k concentration declines in both cell types; the concentration of parvalbumin- $\beta$ also falls in inner hair cells but rises dramatically in outer hair cells and has still not reached a plateau at P26 (Fig. 5). In terms of their complement of calciumbinding proteins, inner and outer hair cells therefore diverge in a manner reflecting their mature functional specialization. Measurements of both parvalbumin- $\beta$ and calbindin-D28k in P26 inner hair cells were indistinguishable from background, suggesting that both proteins are absent from these hair cells. The absence of parvalbumin- $\beta$ agrees with the findings of Sakaguchi et al. (1998).

Differences between apical and basal locations were seen for both calbindin-D28k and parvalbumin- $\beta$ in outer hair cells, but these were in opposite directions, with parvalbumin- $\beta$ increasing slightly and calbindin-D28k decreasing markedly toward the basal high-frequency end (Fig. 5). Outer hair cell concentrations at P26 for apical and basal positions were, respectively, $1954 \pm$ $151 \mu \mathrm{M}(n=268)$ and $2892 \pm 120 \mu \mathrm{M}(n=225)$ for parvalbumin $-\beta$ and $230 \pm 38 \mu \mathrm{M}(n=117)$ and $15 \pm 11 \mu \mathrm{M}(n=$ $57)$ for calbindin-D28k. The lower amount of calbindin-D28k found at the basal location agrees with previous results for this protein (Imamura and Adams, 1996). Because of the opposing gradients, the total number of calcium-binding sites is similar at the two positions. Taking into account that parvalbumin- $\alpha$ and parvalbumin- $\beta$ bind two $\mathrm{Ca}^{2+}$ ions whereas calbindin-D28k binds four (Celio et al., 1996), there are $5.4 \mathrm{mM} \mathrm{Ca}^{2+}$-binding sites in apical outer hair cells and $6.0 \mathrm{~mm}$ in basal cells. The equivalent concentrations of $\mathrm{Ca}^{2+}$-binding sites for the inner hair cells are $0.53 \mathrm{~mm}$ at the apex and $0.49 \mathrm{~mm}$ at the base, values that are dominated by parvalbumin- $\alpha$. Expressed in this way, inner hair cells have $1 / 10$ the amount of calcium buffer compared with outer hair cells.

\section{Stereociliary concentrations of calcium-binding proteins}

Radial sections of both outer and inner hair cells suggested a lower concentration of parvalbumin- $\beta$ and calbindin-D28k in the stereocilia than in the cell body (for parvalbumin- $\beta$, see Fig. $2 B$; for calbindin-D28k, see Fig. $3 A$ ). This observation may have 
arisen because the stereocilia are $\sim 200 \mathrm{~nm}$ in diameter and of similar dimensions to the thickness of the longitudinal sections, which was $120 \mathrm{~nm}$. Therefore, the stereocilia may not appear on both surfaces (i.e., they may not occupy the full width of the section), which would reduce the labeling compared with that of the much wider, $\sim 5 \mu \mathrm{m}$ cell body. To ensure that their profiles were exposed on both sides of each section and to explore this observation more quantitatively, immunogold counts were performed on horizontal sections of outer hair cells at a single midfrequency location (for calbindin-D28k, see Fig. 6, $A, B$; for parvalbumin- $\beta$, see $C$ ). For calbindin-D28k, the inferred concentration was $20 \mu \mathrm{M}$ for the stereocilia and $99 \mu \mathrm{M}$ for the apical cytoplasm. For parvalbumin- $\beta$, the equivalent concentrations were $969 \mu \mathrm{M}$ for the stereocilia and $3392 \mu \mathrm{M}$ for the apical cytoplasm. These numbers indicate reduced levels in the stereocilia for both proteins, with calbindin-D28k showing a larger fivefold attenuation than 3.5-fold for parvalbumin- $\beta$. The lower stereociliary concentration cannot be simply attributable to exclusion from an actin network because the labeling in the actin meshwork of the cuticular plate was larger than in either stereocilia or the apical cell body. However, it is conceivable that the paracrystalline array of cross-linked actin filaments in the stereocilia substantially reduces the cytoplasmic volume. Mammalian stereocilia, $200 \mathrm{~nm}$ in diameter, contain $\sim 300$ actin filaments (Engström and Engström, 1978). If each filament is assumed to be a cylinder $\sim 6 \mathrm{~nm}$ in diameter, the actin occupies $\sim 27 \%$ of the total stereociliary volume. A similar value for the excluded volume was obtained using several different approaches by Lumpkin and Hudspeth (1998). However, this value represents a lower limit because it ignores the volume of cross-linking proteins such as I-plastin and espin. Nevertheless, the excluded volume seems too small to account for a fivefold lower concentration of calbindin-D28k in stereocilia; this difference and the greater reduction in calbindin-D28k (28 kDa) than parvalbumin- $\beta$ (12 $\mathrm{kDa}$ ) implies a size-dependent diffusion barrier for penetration of these proteins from the cell body into the hair bundle. It is conceivable that the actin filaments and their associated crosslinking protein comprise a molecular sieve that tends to hinder diffusion of large cytoplasmic proteins within the stereocilia. However, an argument against this notion is that no comparable exclusion of calbindin-D28k and parvalbumin- $\beta$ from the stereocilia was seen in turtle auditory hair cells in which both proteins had similarly high concentrations in the hair bundle and cell body (Hackney et al., 2003, their Figs. 6, 8). As an indicator of the molecular sieving in the stereociliary shaft, the packing density of the actin filaments at $\sim 6000$ filaments $/ \mu \mathrm{m}^{2}$ is similar in hair cells of mammals (Engström and Engström, 1978) and non-mammals such as the alligator lizard (Tilney et al., 1980). The diffusion barrier, if it exists, may be located not in the stereociliary shafts but in the stereociliary rootlets, which have a different appearance in reptile compared with mammals, displaying a dense osmiophilic staining in mammalian outer hair cells not seen in turtle hair cells (Hackney et al., 1993).

\section{Discussion}

We measured the concentrations of four of the main high-affinity calcium-binding proteins (calbindin-D28k, calretinin, and the $\alpha$ and $\beta$ isoforms of parvalbumin) that can serve as diffusible $\mathrm{Ca}^{2+}$ buffers in mammalian cochlear hair cells. The assay was achieved by calibration of the immunogold labeling against fixed gels containing known amounts of the protein. The method makes no assumption about the protein distribution and enables protein concentrations to be determined in different cell types. Further-
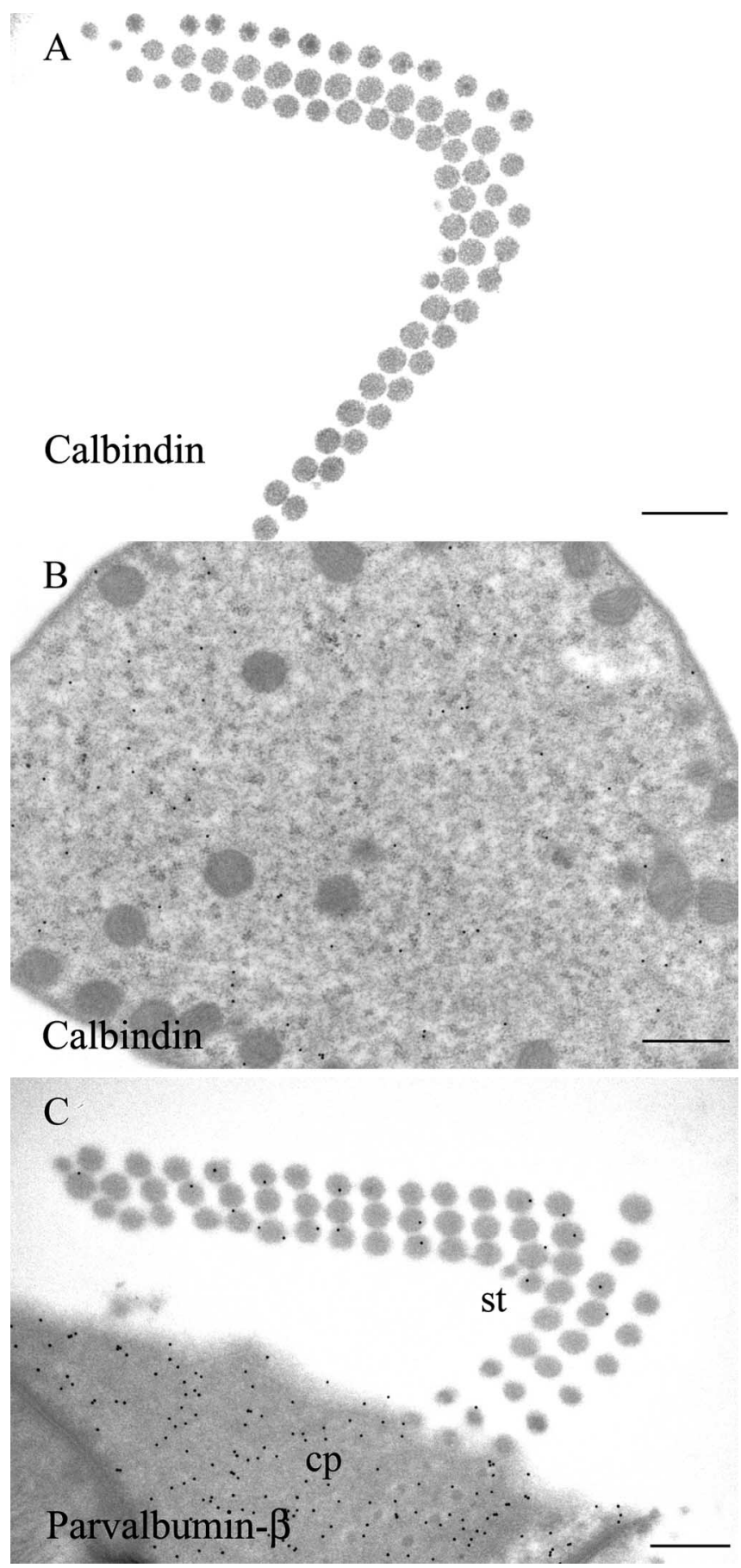

Figure 6. Immunogold labeling for calbindin-D28k and parvalbumin- $\beta$ is lower in the stereocilia than in the cell body. $\boldsymbol{A}$, Calbindin-D28k-labeled section through stereociliary bundle of midfrequency outer hair cell. $\boldsymbol{B}$, Calbindin-D28k-labeled horizontal section of apex of an adjacent outer hair cell in the same section as that in $\boldsymbol{A}$. Note the sparse labeling in the stereocilia compared with that in the apical cytoplasm. $C$, Parvalbumin- $\beta$-labeled section through the stereociliary bundle (st) and the cuticular plate (cp) of the same outer hair cell. Note the reduced labeling in the stereocilia and also note that the labeling that is present tends to be found toward the periphery of the stereocilium. All sections are from a P26 rat. Scale bars, $0.5 \mu \mathrm{m}$.

more, the inferred protein concentration does not depend on the efficacy of the antibody, because the same antibody dilution was used to label sections of tissue and protein gel on the same grid and under identical conditions. The postembedding technique relies on antibodies binding to epitopes that are exposed on the surface of the section (for both tissue and gel). This allows surface 
labeling to be translated into a volume concentration provided the protein has the same conformation and antibody sensitivity in the gel as in the cell cytoplasm. One factor that could invalidate this assumption is if the $\mathrm{Ca}^{2+}$-bound and $\mathrm{Ca}^{2+}$-free forms of the protein were antigenically different (Winsky and Kuznicki, 1996) and if the relative amounts of the bound and free forms were different in the gel and the cytoplasm. There is evidence that these proteins undergo conformational changes on binding $\mathrm{Ca}^{2+}$ [parvalbumin, (Hutnik et al., 1990), calbindin-D28k (Berggard et al., 2002)] that might alter the exposed epitopic sites and hence change the sensitivity to a particular antibody. This might explain why different antibodies to the same protein in some cases (e.g., parvalbumin- $\alpha$ ) gave different values for the concentrations. Despite this possible complication, application of the technique to cerebellar Purkinje cells yielded concentrations for calbindinD28k and parvalbumin- $\alpha$ within the range of values obtained using other methods.

All of the proteins studied have been immunolocalized previously to the hair cells (Dechesne et al., 1994; Pack and Slepecky, 1995; Soto-Prior et al., 1995; Imamura and Adams, 1996; Sakaguchi et al., 1998), but previous studies gave no absolute concentrations. Our most striking observation was the upregulation through the onset of hearing of parvalbumin- $\beta$ in outer hair cells to a millimolar level, 10 times that of the next most concentrated protein, calbindin-D28k. This result agrees with Yang et al. (2004) who used both immunohistochemistry and in situ hybridization to demonstrate increased amounts of parvalbumin- $\beta$ in developing rat outer hair cells. They observed that parvalbumin- $\beta$ was confined to outer hair cells and its concentration peaked at $\mathrm{P} 10$ at $2 \mathrm{ng} / \mu \mathrm{g}$ of organ of Corti. This tissue level can be converted to a hair cell concentration knowing the volume fraction occupied by outer hair cells and the density of cytoplasm $(\sim 1 \mathrm{~kg} / \mathrm{L})$. Stereological measurements in P16 and P26 rats showed that outer hair cells contribute 8-9\% (mean of apical and basal locations) of the cellular volume of the rat organ of Corti. Using this volume fraction, we infer from the measurements of Yang et al. (2004) an average parvalbumin- $\beta$ concentration in these hair cells of $\sim 2.0 \mathrm{mM}$, which agrees well with our values from quantifying the immunogold labeling (Fig. $4 B$ ). It is worth noting that the upregulation of the cytoplasmic $\mathrm{Ca}^{2+}$-buffering protein, parvalbumin- $\beta$, through the onset of hearing parallels other changes that may be related to $\mathrm{Ca}^{2+}$ homeostasis in outer hair cells at approximately this time. These include the appearance and maturation of the subsurface cisternae lining the lateral membrane (Pujol et al., 1991; Weaver and Schweitzer, 1994) and the increased expression of the cytoplasmic CaATPase in the cisternae (Schulte, 1993; Zine and Schweitzer, 1996). All of these changes imply an increased $\mathrm{Ca}^{2+}$ turnover in adult outer hair cells.

Our results demonstrate that parvalbumin- $\beta$ and calbindinD28k contribute between 5.4 and $6.0 \mathrm{~mm}$ total calcium-binding sites in outer hair cells of P26 rats with fully developed hearing. The corresponding values for inner hair cells, attributable mainly to parvalbumin- $\alpha$ and calretinin, were 10 -fold less, $0.53 \mathrm{~mm}$ at the apical low-frequency location and $0.49 \mathrm{~mm}$ at the basal highfrequency location. Because of the limited availability of the parvalbumin- $\beta$ protein, determining its concentration in the gel required extrapolation based on the linearity derived from the two gel concentrations. Because the immunogold labeling will eventually saturate with increasing antigen concentration, the extrapolation would, if anything, lead to an underestimate of the tissue concentration, which means that the concentration of parvalbumin- $\beta$ in outer hair cells may be even larger than calcu- lated. Calmodulin is another calcium-binding protein that is well represented in inner hair cells (Pack and Slepecky, 1995; Imamura and Adams, 1996; Nakazawa, 2001) and may aid in calcium buffering, but much of it is probably bound to immobilized target proteins. Physiological measurements have also provided information about calcium buffering in hair cells. Inhibition of exocytosis by calcium buffers in post-hearing mouse inner hair cells implied a low endogenous buffer concentration, equivalent to 0.1 mM EGTA (Moser and Beutner, 2000). A quantitative comparison of the two sets of results is hampered by the different calcium-binding properties of EGTA and the proteins. EGTA is a slow buffer with a $\mathrm{Ca}^{2+}$ dissociation constant, $K_{\mathrm{D}}$, of $0.18 \mu \mathrm{M}$ (Naraghi, 1997). Although detailed binding kinetics are not available for calretinin (Edmonds et al., 2000; Schwaller et al., 2002), it probably resembles calbindin-D28k in being a relatively lowaffinity buffer $\left(K_{\mathrm{D}}\right.$ of $\left.0.2-0.5 \mu \mathrm{M}\right)$ with fast calcium-binding kinetics (Nägerl et al., 2000), whereas parvalbumin- $\alpha$, in the presence of magnesium, behaves as a relatively high-affinity buffer $\left(K_{\mathrm{D}}\right.$ of $\sim 50 \mathrm{nM}$ ) with slow binding kinetics (Lee et al., 2000; Henzl et al., 2003). An additional complication is the possibility that a fraction of the calcium-binding protein is nondiffusible. For calbindin-D28k, more than one-third may be immobilized (Hubbard and McHugh, 1995). Nevertheless, both physiological and immunohistochemical results suggest a relatively low level of calcium buffering in inner hair cells. Low $\mathrm{Ca}^{2+}$ buffering may be crucial for enabling large fast calcium transients to rapidly replenish the synaptic release sites and facilitate fast and sustained exocytosis required for high-frequency phase locking of auditory neurons. In addition, the partial exclusion of proteinaceous buffer from the stereocilia implies a very low calcium buffer in the vicinity of the mechanotransducer channels. Besides differences in calcium buffers, other differences in $\mathrm{Ca}^{2+}$ handling exist between inner and outer hair cells. The plasma membrane CaATPase is highly concentrated in the soma but not the stereocilia of inner hair cells, whereas the converse is true in outer hair cells, in which the CaATPase is mainly confined to the stereocilia (Dumont et al., 2001). These differences imply that the spatial localization of $\mathrm{Ca}^{2+}$ is quite different in the two hair cell types.

The large amount of proteinaceous calcium buffer in outer hair cells, similar only to the millimolar concentrations of parvalbumin- $\alpha$ in skeletal muscle, is puzzling and implies that $\mathrm{Ca}^{2+}$ plays an important role in outer hair cell function. In skeletal muscle, large $\mathrm{Ca}^{2+}$ transients spread through the fiber to initiate the contractile process, and binding of $\mathrm{Ca}^{2+}$ by parvalbumin- $\alpha$ is important in facilitating relaxation. The relative amounts of parvalbumin- $\alpha$ in different muscle types are correlated with the relaxation rate (Heizmann et al., 1982), and fast twitch muscles in parvalbumin- $\alpha$ knock-outs show prolonged contraction-relaxation cycles (Schwaller et al., 1999). The two firmly established roles for $\mathrm{Ca}^{2+}$ in outer hair cells are in regulating adaptation of the mechanotransducer channels (Kennedy et al., 2003) and mediating the cholinergic efferent response (Fuchs, 1996; Oliver et al., 2000). For control of transduction, $\mathrm{Ca}^{2+}$ enters through the mechanotransducer channels and is extruded via a stereociliary plasma membrane CaATPase, local elevations in $\mathrm{Ca}^{2+}$ occurring only in the hair bundle. It has been proposed that parvalbumin- $\beta$ may be linked to operation of the cholinergic efferent system (Yang et al., 2004). Rat outer hair cells receive efferent innervation throughout the cochlea, with somewhat higher density at the base (Dannhof and Bruns, 1993). In its role in efferent transmission, $\mathrm{Ca}^{2+}$ enters through neuronal nicotinic ACh receptors to activate $\mathrm{Ca}^{2+}$-activated $\mathrm{K}^{+}$channels, but the $\mathrm{Ca}^{2+}$ signal will be primarily limited to the space between the 
cisternae and the plasma membrane. A third but incompletely understood role of $\mathrm{Ca}^{2+}$ in outer hair cells is in regulating somatic electromotility (Dulon et al., 1990; Frolenkov et al., 2000; Beurg et al., 2001), which has been proposed as a mechanism for the slow efferent effects (Dallos et al., 1997; Sridhar et al., 1997). Is it possible there are large cytoplasmic transients in $\mathrm{Ca}^{2+}$ produced by $\mathrm{Ca}^{2+}$-induced $\mathrm{Ca}^{2+}$ release from the subsurface cisternae reminiscent of the sarcoplasmic reticulum in muscle (Saito 1983; Bannister et al., 1988)?

Because the physiological role of $\mathrm{Ca}^{2+}$ in the outer hair cell motility is not well defined, it is not straightforward to design experiments to uncover the need for millimolar concentrations of calcium buffer. If $\mathrm{Ca}^{2+}$ is mainly associated with control of motility, possibly a slow version (Dulon et al., 1990), neither the release mechanism nor mode of action of the divalent is properly understood. Nevertheless, it can be speculated that the large amount of endogenous calcium buffer will accelerate $\mathrm{Ca}^{2+}$ transients, as it does in skeletal muscle, and also shield the subcellular organelles from large excursions in intracellular $\mathrm{Ca}^{2+}$ occurring near the plasma membrane. In this respect, the calcium buffer may be a crucial protection against the deleterious consequences of $\mathrm{Ca}^{2+}$ loading that follow acoustic overstimulation (Fridberger et al., 1998).

\section{References}

Baimbridge KG, Miller JJ, Parkes CO (1982) Calcium-binding protein distribution in the rat brain. Brain Res 239:519-525.

Bannister LH, Dodson HC, Astbury AR, Douek EE (1988) The cortical lattice: a highly ordered system of subsurface filaments in guinea pig cochlear outer hair cells. Prog Brain Res 74:213-219.

Berggard T, Miron S, Onnerfjord P, Thulin E, Akerfeldt KS, Enghild JJ, Akke M, Linse S (2002) Calbindin D28k exhibits properties characteristic of a $\mathrm{Ca}^{2+}$ sensor. J Biol Chem 277:16662-16672.

Beurg M, Bouleau Y, Dulon D (2001) The voltage-sensitive motor protein and the $\mathrm{Ca}^{2+}$-sensitive cytoskeleton in developing rat cochlear outer hair cells. Eur J Neurosci 14:1947-1952.

Blatchley BJ, Cooper WA, Coleman JR (1987) Development of auditory brainstem response to tone pip stimuli in rat. Dev Brain Res 32:75-84.

Brandt A, Striessnig J, Moser T (2003) $\mathrm{Ca}_{\mathrm{V}} 1.3$ channels are essential for development and presynaptic activity of cochlear inner hair cells. J Neurosci 23:10832-10840.

Celio MR, Pauls T, Schwaller B (1996) Guidebook to calcium-binding proteins. New York: Oxford UP.

Crowley DE, Hepp-Reymond MC (1966) Development of cochlear function in the ear of the infant rat. J Comp Physiol Psychol 62:427-432.

Dallos P (1992) The active cochlea. J Neurosci 12:4575-4585.

Dallos P, He DZ, Lin X, Sziklai I, Mehta S, Evans BN (1997) Acetylcholine, outer hair cell electromotolity, and the cochlear amplifier. J Neurosci 17:2212-2226.

Dannhof BJ, Bruns V (1993) The innervation of the rat organ of Corti. Hear Res 66:8-22.

Dechesne CJ, Winsky L, Kim HN, Goping G, Vu TD, Wenthold RJ, Jacobitz DM (1991) Identification and ultrastructural localization of calretininlike calcium-binding protein (protein 10) in guinea pig and rat inner ear. Brain Res 560:39-148.

Dechesne CJ, Rabejac D, Desmadryl G (1994) Development of calretinin immunoreactivity in the mouse inner ear. J Comp Neurol 346:517-529.

Dulon D, Zajic G, Schacht J (1990) Increasing intracellular free calcium induces circumferential contractions in isolated cochlear outer hair cells. J Neurosci 10:1388-1397.

Dumont RA, Lins U, Filoteo AG, Penniston JT, Kachar B, Gillespie PG (2001) Plasma membrane $\mathrm{Ca}^{2+}$-ATPase isoform 2a is the PMCA of hair bundles. J Neurosci 21:5066-5078.

Edmonds B, Reyes R, Schwaller B, Roberts WM (2000) Calretinin modifies presynaptic calcium signaling in frog saccular hair cells. Nat Neurosci 3:786-790.

Engström H, Engström B (1978) Structure of the hairs on cochlear sensory cells. Hear Res 1:49-66.
Fettiplace R, Ricci AJ (2003) Adaptation in auditory hair cells. Curr Opin Neurobiol 13:446-451.

Fridberger A, Flock A, Ulfendahl M, Flock B (1998) Acoustic overstimulation increases outer hair cell $\mathrm{Ca}^{2+}$ concentrations and causes dynamic contractions of the hearing organ. Proc Natl Acad Sci USA 95:7127-7132.

Frolenkov GI, Mammano F, Belyantseva IA, Coling D, Kachar B (2000) Two distinct $\mathrm{Ca}^{2+}$-dependent signaling pathways regulate the motor output of cochlear outer hair cells. J Neurosci 20:5940-5948.

Fuchs PA (1996) Synaptic transmission at vertebrate hair cells. Curr Opin Neurobiol 6:514-519.

Fuchs PA, Glowatski E, Moser T (2003) The afferent synapse of cochlear hair cells. Curr Opin Neurobiol 13:452-458.

Hackney CM, Fettiplace R, Furness DN (1993) The functional morphology of stereociliary bundles on turtle cochlear hair cells. Hear Res 69:163-175.

Hackney CM, Mahendrasinam S, Jones EMC, Fettiplace R (2003) The distribution of calcium buffering proteins in the turtle cochlea. J Neurosci 23:4577-4589.

Heizmann CW, Berchtold MW, Rowlerson AM (1982) Correlation of parvalbumin concentration with relaxation speed in mammalian muscles. Proc Natl Acad Sci USA 79:7243-7247.

Henzl MT, Larson JD, Agah S (2003) Estimation of parvalbumin $\mathrm{Ca}^{2+}$ - and $\mathrm{Mg}^{2+}$-binding constants by global least-squares analysis of isothermal titration calorimetry data. Anal Biochem 319:216-233.

Hubbard MJ, McHugh NJ (1995) Calbindin $28 \mathrm{kDa}$ and calbindin $30 \mathrm{kDa}$ (calretinin) are substantially localised in the particulate fraction of rat brain. FEBS Lett 374:333-337.

Hutnik CM, MacManus JP, Szabo AG (1990) A calcium-specific conformational response of parvalbumin. Biochemistry 29:7318-7328.

Imamura S, Adams JC (1996) Immunolocalization of peptide 19 and other calcium-binding proteins in the guinea-pig cochlea. Anat Embryol 194:407-418.

Kennedy HJ, Evans MG, Crawford AC, Fettiplace R (2003) Fast adaptation of mechanoelectrical transducer channels in mammalian cochlear hair cells. Nat Neurosci 6:832-836.

Kosaka T, Kosaka K, Nakayama T, Hunziker W, Heizmann CW (1993) Axons and axon terminals of cerebellar Purkinje-cells and basket cells have higher levels of parvalbumin immunoreactivity than somata and dendrites-quantitative analysis by immunogold labeling. Exp Brain Res 93:483-491.

Kozel PJ, Friedman RA, Erway LC, Yamoah EN, Liu LH, Riddle T, Duffy JJ, Doetschman T, Miller ML, Cardell EL, Schull GE (1998) Balance and hearing deficits in mice with a null mutation in the gene encoding plasma membrane $\mathrm{Ca}^{2+}$-ATPase isoform 2. J Biol Chem 273:18693-18696.

Lee S-H, Schwaller B, Neher E (2000) Kinetics of $\mathrm{Ca}^{2+}$ binding to parvalbumin in bovine chromaffin cells: implications for $\left[\mathrm{Ca}^{2+}\right]$ transients in neuronal dendrites. J Physiol (Lond) 525:419-432.

Lumpkin EA, Hudspeth AJ (1998) Regulation of free $\mathrm{Ca}^{2+}$ concentration in hair-cell stereocilia. J Neurosci 18:6300-6318.

Moser T, Beutner D (2000) Kinetics of exocytosis and endocytosis at the cochlear inner hair cell afferent synapse of the mouse. Proc Natl Acad Sci USA 97:883-888.

Müller M (1991) Frequency representation in the rat cochlea. Hear Res $51: 247-254$.

Nägerl UV, Novo D, Mody I, Vergara JL (2000) Binding kinetics of calbindin-D28k determined by flash photolysis of caged $\mathrm{Ca}^{2+}$. Biophys J 79:3009-3018

Nakazawa K (2001) Ultrastructural localization of calmodulin in gerbil cochlea by immunogold electron microscopy. Hear Res 151:133-140.

Naraghi M (1997) T-jump kinetics of calcium binding kinetics of calcium chelators. Cell Calcium 22:255-268.

Oliver D, Klocker N, Schuck J, Baukrowitz T, Ruppersberg JP, Fakler B (2000) Gating of $\mathrm{Ca}^{2+}$-activated $\mathrm{K}^{+}$channels controls fast inhibitory synaptic transmission at auditory outer hair cells. Neuron 26:595-601.

Pack AK, Slepecky NB (1995) Cytoskeletal and calcium-binding proteins in the mammalian organ of Corti: cell type specific proteins displaying longitudinal and radial gradients. Hear Res 91:119-135.

Pauls TL, Cox JA, Berchtold MW (1996) The $\mathrm{Ca}^{2+}$-binding proteins parvalbumin and oncomodulin and their genes: new structural and functional findings. Biochim Biophys Acta 1306:39-54.

Plogmann D, Celio MR (1993) Intracellular concentration of parvalbumin in nerve cells. Brain Res 600:273-279.

Pujol R, Zajic G, Dulon D, Raphael Y, Altschuler RA, Schacht J (1991) First 
appearance and development of motile properties in outer hair cells isolated from guinea-pig cochlea. Hear Res 57:129-141.

Roberts WM (1994) Localization of calcium signals by a mobile calcium buffer in frog saccular hair cells. J Neurosci 14:3246-3262.

Saito K (1983) Fine structure of the sensory epithelium of guinea-pig organ of Corti: subsurface cisternae and lamellar bodies in the outer hair cells. Cell Tissue Res 229:467-481.

Sakaguchi N, Henzl MT, Thalmann I, Thalmann R, Schulte BA (1998) Oncomodulin is expressed exclusively in outer hair cells in the organ of Corti. J Histochem Cytochem 46:29-39.

Schulte BA (1993) Immunohistochemical localization of intracellular Ca-ATPase in outer hair cells, neurons and fibrocytes in the adult and developing inner ear. Hear Res 65:262-273.

Schwaller B, Dick J, Dhoot G, Carroll S, Vrbova G, Nicotera P, Pette D, Wyss A, Bluethmann H, Hunziker W, Celio MR (1999) Prolonged contraction-relaxation cycle of fast-twitch muscles in parvalbumin knockout mice. Am J Physiol 276:C395-C403.

Schwaller B, Meyer M, Schiffmann S (2002) "New" functions for "old" proteins: the role of the calcium-binding proteins calbindin D-28k, calretinin and parvalbumin in cerebellar physiology. Studies with knockout mice. Cerebellum 1:241-258.

Soto-Prior A, Cluzel M, Renard N, Ripoll C, Lavigne-Rebillard M, Eybalin M, Hamel CP (1995) Molecular cloning and expression of alpha parvalbumin in the guinea pig cochlea. Brain Res Mol Brain Res 34:337-342.
Sridhar TS, Brown MC, Sewell WF (1997) Unique postsynaptic signaling at the hair cell efferent synapse permits calcium to evoke changes on two time scales. J Neurosci 17:428-437.

Street VA, McKee-Johnson JW, Fonseca RC, Tempel BL, Noben-Trauth K (1998) Mutations in plasma membrane $\mathrm{Ca}^{2+}$-ATPase gene causes deafness in deafwaddler mice. Nat Genet 19:390-394.

Tilney LG, Derosier DJ, Mulroy MJ (1980) The organization of actin filaments in the stereocilia of cochlear hair cells. J Cell Biol 86:244-259.

Tucker T, Fettiplace R (1995) Confocal imaging of calcium microdomains and calcium extrusion in turtle hair cells. Neuron 15:1323-1335.

Uziel A, Romand R, Marot M (1981) Development of cochlear potentials in rats. Audiology 20:89-100.

Weaver SP, Schweitzer L (1994) Development of gerbil outer hair cells after the onset of cochlear function: an ultrastructural study. Hear Res 72:44-52.

Winsky L, Kuznicki J (1996) Antibody recognition of calcium-binding proteins depends on their calcium-binding status. J Neurochem 66:764-771.

Yamoah EN, Lumpkin EA, Dumont RA, Smith PJ, Hudspeth AJ, Gillespie PG (1998) Plasma membrane $\mathrm{Ca}^{2+}$-ATPase extrudes $\mathrm{Ca}^{2+}$ from hair cell stereocilia. Neuroscience 15:610-624.

Yang D, Thalmann I, Thalmann R, Simmons DD (2004) Expression of $\alpha$ and $\beta$-parvalbumin is differentially regulated in the rat organ of Corti during development. J Neurobiol 58:479-492.

Zine A, Schweitzer L (1996) Development of intracellular Ca-ATPase in the gerbil outer hair cell lateral wall. Brain Res 721:1-10. 